\section{Analysis of Consumer Purchases of Floral Products in Supermarkets}

\author{
Bridget K. Behe ${ }^{1}$, Timothy A. Prince ${ }^{2}$, and Harry K. Tayama ${ }^{3}$ \\ Department of Horticulture, The Ohio State University, Columbus, \\ $\mathrm{OH}$ 43210-1096
}

Additional index words. consumer behavior, marketing, multivariate analysis

\begin{abstract}
Survey analysis of $\mathbf{5 1 0}$ floral product consumers in Ohio supermarkets identified 34 factors that affect floral purchasing. Responses to 106 survey questions were factor-analyzed using a principal component analysis with varimax rotate that yielded 34 independent factors, accounting for $64 \%$ of the total variance. Factors were grouped into five major categories: product, consumer, store, use (gift), and use (location) factors. The analysis condensed the domain of consumer floral purchasing issues into fewer factors that represent the most important influences on floral buying decisions. The factors are useful in market segmentation and were used to define five market segments of supermarket-floral customers.
\end{abstract}

Traditionally, floral sales were made through a retail florist for holidays, funerals, and weddings (Sherman et al., 1956). Floral retailing has changed dramatically in the past decade. One substantial change was increased merchandising of floral products through mass markets, especially supermarkets. Initially, supermarkets entered the market to alleviate seasonal surpluses in supply experienced by local flower growers (Goodrich, 1980). However, supermarkets now maintain $12 \%$ to $15 \%$ of the total flower retail market (Kress, 1987).

Previous research identified consumers who purchased fresh floral products from any retail outlet (Sherman et al., 1956) and identified consumer product preferences (Hutchinson and Robertson, 1979; Miller, 1977; Robertson and Hahn, 1978). Profiles of consumers who purchased floral products from supermarkets were made based on demographics and a few psychographic characteristics (Baker, 1961; Market Facts, 1985, 1989; Miller, 1977).

Managers of supermarkets and traditional retail florists need more information about their customers. Marketing strategies focus on demographic characteristics rather than the domain of purchasing issues. Additional consumer research examining behavioral and psychographic factors that affect consumer floral purchases in the supermarket would

Received for publication 28 Dec. 1990. Accepted for publication 9 Dec. 1991. Journal Article no. 324-90. Salary support provided by state and federal funds appropriated to the Ohio Agricultural Research and Development Center, The Ohio State Univ. We greatly appreciate the financial support of this research by the Produce Marketing Association, Ohio Floriculture Foundation, and Ohio Florists Association. The cost of publishing this paper was defrayed in part by the payment of page charges. Under postal regulations, this paper therefore must be hereby marked advertisement solely to indicate this fact.

${ }^{1}$ Former Graduate Research Associate. Presently, Assistant Professor, Dept. of Horticulture, Aubum Univ.. AL 36849-5408.

${ }^{2}$ Former Assistant Professor of Horticulture. ${ }^{3}$ Professor of Horticulture, Emeritus. benefit supermarket and traditional retail florist management in making more informed decisions concerning future product merchandising strategies. Understanding the range of components that affect the consumer's decision to buy flowers would help management better meet consumers' needs. Therefore, the objective of this research was to identify principal factors that affect the permarkets.

A structured response questionnaire was developed and tested to measure 35 attitudinal, 63 product, and eight consumer demographic characteristics. These characteristics were measured with nominal, 5-point semantic differential, 5-point Likert (Peterson, 1982), and 5- and 9-point ordinal scales. A floral product was defined for the participants as any fresh floral product, including cut flowers, potted blooming plants, foliage plants, and bedding plants. The survey was pretested in Oct. 1984 in a Columbus, Ohio, supermarket and modified to aid in the participant's interpretation of specific questions.

Questionnaires were distributed in Nov. and Dec. 1984 directly to consumers as they shopped in the supermarket. Surveys (1369) were distributed throughout eight Ohio supermarkets of two national chains and one regional supermarket chain. Interviewers intercepted store customers who paused at a floral display. The interviewer introduced himself/herself as an Ohio State Univ. student and asked the customer if she/he would be willing to complete a questionnaire at home. A short description of the purpose of cifically, participants were informed that the study was intended to improve the assortment and quality of floral products in the marketplace. The customer was instructed to mail the completed form to the university in a self-addressed, postage-paid envelope that was included with the survey form. Data collection was terminated on $28 \mathrm{Feb}$. 1985. Of the 1369 surveys distributed, 510 were returned for analysis, yielding a 37\% response rate. consumer's floral purchase decision in suthe study was explained to participants. Spe-
Ninety-one survey questions were factoranalyzed (Broschat, 1979) to yield 34 orthogonal factors. Principal-components factor analysis was used to extract the major independent sources of variance among the questions (Green, 1978). The principal-components solutions used Kaiser's varimax rotation procedure to define the interrelated issues more clearly (Kaiser, 1958). All factors with eigenvalues $>1$ were retained for interpretation (Guttman, 1954).

The factors were interpreted from the survey questions with the highest loadings on the factor. Factor loadings indicate the direction and degree of relationship between the factor and original question. Communalities represented the amount of variance each question contributed to the factor solution, indicating the question's importance in the final solution. The factors were grouped into five categories for ease of explanation: product, consumer, store, use (location), and use (gift recipient).

Mail-survey research has been used as an acceptable method with minimal systematic bias (Berkeoven et al., 1975). The use of mail surveys rather than telephone surveys and personal interviews allows more depth in the questioning and greater breadth of issues. The response rate of $37 \%$ was higher than typically received from mailing survey methods and was likely due to increased participant interest or personal contact made during survey distribution (Dillman, 1978).

Factor analysis has been used in survey research as a data-reduction technique to define factors underlying separately measured quantitative variables (Broschat, 1979). The varimax rotation yielded a factor solution of independent factors that are more clearly interpreted than a nonrotated solution. The analysis yielded 34 factors that were grouped into five categories: nine consumer factors, eight product factors, two store factors, nine gift (use) factors, and six location (of use) factors. Although the factors are mathematically independent, grouping the factors into five categories made explanation easier.

Consumer factor 1 (Table 1) defined the number of floral purchases a consumer made in the previous year. It was comprised of several issues in decreasing order of factor loadings and communalities, including number of floral purchases from a supermarket, total number of floral purchases in the past year, and number of special trips to the supermarket for floral products in the previous year. Consumer attitudinal issues that comprised this factor, in similar order, included 1) usually having floral products in the home, 2) buying floral products for no special reason, 3) the ability to afford floral products on everyday occasions, and 4) giving flowers on everyday occasions. The emergence of factor 1 indicated that past purchase experience influenced the decision to buy more floral products.

Consumer factor 2 measured the purchaser's propensity to buy flowers for personal use and was comprised of 1) the consumer's liking to buy floral products for personal use, 2) having bought flowers for 
Table 1. Factor-loading matrix of floral purchase variables (survey issues) on nine consumer factors.

Consumer factor and description Variables (survey issues) Loadingy Communality

1) Number of floral purchases

Number of purchases from supermarket

Number of purchases in past year

Number of special trips to supermarket

Usually have flowers at home

Can afford flowers on everyday occasions

Bought for no special reason

Flowers should be given for everyday occasions

2) Personal use

Like to buy for self

Bought for self

Enjoy giving as much as receiving

3) Do-it-yourself

Grow own flowers for cuts

Prefer home-grown flowers over store-bought ones

Like to arrange own flowers

Know names of flowers and plants

4) Planned purchases

Flowers on shopping list before bought

Plan to buy flowers before seeing

Know what kind wanted before buying

Know how to make flowers last

Use some additive with water for cut flowers

0.74

$0.81 \quad 0.77$

0.74

0.78

$0.63 \quad 0.67$

$0.56 \quad 0.67$

$0.53 \quad 0.61$

$0.51 \quad 0.65$

$0.44 \quad 0.58$

$0.72 \quad 0.70$

$0.71 \quad 0.68$

$0.53 \quad 0.65$

$0.72 \quad 0.69$

0.71

0.49

0.67

0.64

0.41

0.60

0.74

0.68

0.73

0.67

0.65

5) Postproduction knowledge

6) Try new kinds of flowers

Novel floral product preferred over traditional ones Like to try new kinds of floral products

0.75

0.47

0.72

7) Value added

I agree that flowers that are not arranged (in bunches)

0.77

0.65 should be priced the same as arranged flowers

8) Assistance in product selection
0.76

0.65 flowers I buy constructive manner and was termed "do-ityourself." This factor was measured by survey issues including 1) growing one's own flowers for use as fresh cut flowers, 2) preferring home-grown flowers over store-purchased flowers, 3) liking to arrange one's own flowers, and 4) knowing the names of flowers and plants before purchasing them. The degree of consumer involvement with the product to increase the value, as designing or producing flowers, was a separate influence on the purchase of flowers.

Consumer factor 4 described the degree of the consumer's prior planning in purchasing floral products. Survey issues that measured this factor included 1) having flowers on a shopping list before buying them, 2) planning to buy flowers before seeing them, and 3 ) knowing what kind of floral product was desired before a purchase was made. The degree of prior planning for product purchases, either deliberate or spontaneous purchasing, can affect the purchase decision.

Consumer factor 5 identified the consumer's knowledge to extend the postproduction life of floral products. Knowledge of care and handling practices and the use of some additive in the water for fresh cut flowers were strongly associated with this factor. A consumer's degree of postproduction knowledge could be considered to be one component of involvement as was the do-it-yourself factor. In this instance, the knowledge is specific to prolonging the useful life of floral products.

Consumer factor 6 measured the consumer's penchant for trying new types of floral products. Issues that were associated with this factor included 1) a preference for novel types of flowers over traditional flowers and 2) the consumer's desire to try new kinds of floral products. This factor, too, could be considered a component of product involvement. Individuals who may not be adventurous in their product selection may not be as interested nor as curious about product choices as consumers who are more involved in the purchase decision.

Consumer factor 7 defined a consumer's perception of value added. The issue was related to the factor that indicated that a given number of arranged flowers had a higher value than the same number of nonarranged flowers. Valued added has become important in determining price as enhanced products are often priced higher than unaltered products. The consumer's perception of value of design services, or lack thereof, would influence the decision to purchase a specific product.

Consumer factor 8 was a single-issue factor that measured the consumer's preference for having assistance in the floral selection process. Assistance, as a service, may or may not be important to the consumer. This factor indicated that it is, however, a consideration in the floral buying decision.

Consumer factor 9 was a single-issue factor that described how often a consumer shopped for groceries in the supermarket, which was positively related to the number of floral purchases in the supermarket. Their personal use in the previous year, and 3 ) ucts as much as in receiving them. Buying factors for personal use emerged as a separate influence from buying products for other
people, occasions, or places.

Consumer factor 3 described a consumer's likelihood to work with floral products in a 
Table 3. Factor-loading matrix of floral purchase variables (survey issues) on two store factors. ${ }^{\mathrm{z}}$

\begin{tabular}{llll}
\hline \hline $\begin{array}{l}\text { Store factor } \\
\text { and description }\end{array}$ & Variables (survey issues) & Loadingy & Communalityx \\
\hline $\begin{array}{llll}\text { 1) Supermarket } \\
\text { floral image }\end{array}$ & Supermarket floral product quality same as florist & 0.83 & 0.75 \\
& Supermarket flowers as fresh as florist & 0.72 & 0.68 \\
& Supermarket flowers are a better bargain than florist & 0.46 & 0.65 \\
& Supermarket more convenient location to buy than florist & 0.43 & 0.63 \\
& Can afford flowers for everyday occasions & 0.42 & 0.62 \\
& & & \\
2) Floral product & & & \\
assortment & Supermarkets sell the same kinds of flowers as florist & 0.74 & 0.64 \\
\hline
\end{tabular}

${ }^{2}$ Factor loadings are correlations between the variable vector and the factor vector.

y Factor loadings or correlations above 0.40 are reported.

xThe amount of variance in the variable contributing to the factor.

Table 4. Factor-loading matrix of floral purchase variables (survey issues) on nine gift factors. ${ }^{2}$

\begin{tabular}{|c|c|c|c|}
\hline $\begin{array}{l}\text { Gift factor } \\
\text { and description }\end{array}$ & Variables (survey issues) & Loading ${ }^{y}$ & Communality $^{x}$ \\
\hline $\begin{array}{l}\text { 1) Family meal } \\
\text { holiday purchases }\end{array}$ & $\begin{array}{l}\text { Purchased floral product for Easter } \\
\text { Purchased floral product for Thanksgiving } \\
\text { Purchased floral product for Christmas } \\
\text { Place flowers in dining room }\end{array}$ & $\begin{array}{l}0.66 \\
0.54 \\
0.52 \\
0.41\end{array}$ & $\begin{array}{l}0.60 \\
0.61 \\
0.67 \\
0.55\end{array}$ \\
\hline $\begin{array}{l}\text { 2) Purchases for } \\
\text { mother }\end{array}$ & $\begin{array}{l}\text { Bought flowers for parent } \\
\text { Bought flowers for Mother's Day } \\
\text { Bought flowers for birthday } \\
\text { Bought flowers for grandparent }\end{array}$ & $\begin{array}{l}0.77 \\
0.70 \\
0.52 \\
0.45\end{array}$ & $\begin{array}{l}0.67 \\
0.67 \\
0.57 \\
0.62\end{array}$ \\
\hline $\begin{array}{l}\text { 3) Purchases in } \\
\text { sympathy }\end{array}$ & $\begin{array}{l}\text { Bought floral product for Memorial Day } \\
\text { Bought floral product for cemetery } \\
\text { Bought floral product for funeral }\end{array}$ & $\begin{array}{l}0.76 \\
0.70 \\
0.48\end{array}$ & $\begin{array}{l}0.64 \\
0.66 \\
0.62\end{array}$ \\
\hline 4) Purchases for men & $\begin{array}{l}\text { Men like to receive flowers as much as women } \\
\text { Bought floral product for male friend } \\
\text { I like to have flowers near me at work }\end{array}$ & $\begin{array}{l}0.66 \\
0.47 \\
0.40\end{array}$ & $\begin{array}{l}0.55 \\
0.61 \\
0.55\end{array}$ \\
\hline $\begin{array}{l}\text { 5) Purchases for } \\
\text { coworker }\end{array}$ & $\begin{array}{l}\text { Bought flowers for coworker } \\
\text { Bought flowers for office }\end{array}$ & $\begin{array}{l}0.74 \\
0.72\end{array}$ & $\begin{array}{l}0.67 \\
0.70\end{array}$ \\
\hline $\begin{array}{l}\text { 6) Purchases for } \\
\text { women }\end{array}$ & $\begin{array}{l}\text { Bought flowers for spouse } \\
\text { Did not buy flowers for a female friend } \\
\text { Bought flowers for my wedding anniversary }\end{array}$ & $\begin{array}{l}0.77 \\
0.54 \\
0.48\end{array}$ & $\begin{array}{l}0.71 \\
0.60 \\
0.60\end{array}$ \\
\hline $\begin{array}{l}\text { 7) Purchases for } \\
\text { wedding }\end{array}$ & $\begin{array}{l}\text { Bought flowers for daughter } \\
\text { Bought flowers for a wedding } \\
\text { Bought flowers for place of worship }\end{array}$ & $\begin{array}{l}0.62 \\
0.50 \\
0.45\end{array}$ & $\begin{array}{l}0.58 \\
0.58 \\
0.60\end{array}$ \\
\hline $\begin{array}{l}\text { 8) Purchases for } \\
\text { special event }\end{array}$ & $\begin{array}{l}\text { Bought a floral product for special event } \\
\text { Bought a floral product for other relative }\end{array}$ & $\begin{array}{l}0.62 \\
0.41\end{array}$ & $\begin{array}{l}0.59 \\
0.23\end{array}$ \\
\hline $\begin{array}{l}\text { 9) Purchases for } \\
\text { father }\end{array}$ & Bought flowers for Father's Day & 0.69 & 0.66 \\
\hline
\end{tabular}

${ }^{2}$ Factor loadings are correlations between the variable vector and the factor vector.

yFactor loadings or correlations above 0.40 are reported.

xThe amount of variance in the variable contributing to the factor.

exposure to floral products would, logically, be increased with more frequent exposure to the products.

Product factor 1 (Table 2) identified fragrance of a floral product as a factor affecting its purchase. This factor capsulized four survey issues related to fragrance, including 1) the consumer's desire to smell floral products before purchasing them, 2) the consumer's desire for fragrant flowers more than those without fragrance, 3 ) the consumer's desire to touch floral products before purchasing them, and 4) the high importance of nonarranged product. These issues formed a continuum of product style from a formal, designed, and imported product to a casual, natural, and domestically grown product. The product has a definite style associated with it. Style may influence the decision, as the product purchaser appears to have a specific destination in mind for the product.

Product factor 3 defined a continuum of flower postproduction care importance. This factor was comprised of three issues: 1) floral longevity (rated as an unimportant product attribute), 2) care and handling instructions (rated as an unimportant product attribute), and 3) the size of the product as an important product attribute. Factor 3 described an inverse relationship between flower size and postproduction instruction importance. The consumer's knowledge of postproduction life could come from several sources. This information may be contained along with the product and, thus, may be a consideration when the consumer decides to purchase a specific floral product.

Product factor 4 condensed two issues that measured the importance of price: 1) the price of the product was least important and was positively related to the factor and 2) the mix or assortment of the product as an important product attribute. The emergence of Factor 4 indicated that price was perceived to be opposite to the product mix. This perception means that consumers equated a higher-priced floral product with a broader assortment, as found at a traditional florist, and a lowerpriced product with a limited product assortment, as found in traditional supermarket floral departments.

Product factor 5 only defined color, which was the least important product attribute. The emergence of color as a single-issue factor demonstrated the uniqueness of product color in the consumer's view, separate from other attributes.

Product factor 6 identified the floral product package. This factor condensed two issues: 1) the floral package and 2) care and handling instructions. Both questions were positively related to this factor. The relationship of these two variables with the package factor indicated the consumer's perception of care instructions as part of the package rather than as a separate characteristic.

Product factor 7 extracted one issue pertaining to floral product delivery: flowers delivered by the commercial florist have less meaning than flowers delivered by the purchaser. Delivery, being a single-issue factor, indicated its uniqueness in the consumer's mind.

Product factor 8 described an additional factor pertaining to floral product color. This factor defined a continuum of color intensity that the consumer perceived as separate from the actual color of the product, as defined by Product factor 5 . The continuum defined in this factor extended from a bright to a pastel color, indicating that color intensity was perceived as distinct from the color itself. 
Table 5. Factor-loading matrix of floral purchase variables (survey issues) on six location (of use) factors. ${ }^{z}$

\begin{tabular}{llll}
\hline \hline $\begin{array}{l}\text { Location factor } \\
\text { and description }\end{array}$ & Variables (survey issues) & Loading & Communality \\
\hline $\begin{array}{l}\text { 1) Purchases for } \\
\text { outdoors }\end{array}$ & $\begin{array}{l}\text { Bought for outside } \\
\text { Bought for yard } \\
\text { Bought for porch or patio }\end{array}$ & 0.75 & 0.68 \\
& Bought flowers for bathroom & 0.73 & 0.71 \\
$\begin{array}{l}\text { 2) Purchases for } \\
\text { kitchen }\end{array}$ & Bought flowers for kitchen & 0.45 & 0.61 \\
$\begin{array}{l}\text { 3) Like to wear } \\
\text { flowers }\end{array}$ & Like to wear flowers & 0.63 & 0.61 \\
$\begin{array}{l}\text { 4) Purchases for } \\
\text { other rooms }\end{array}$ & Bought flowers for study & 0.59 & 0.54 \\
$\begin{array}{l}\text { 5) Purchases for } \\
\text { other occasions }\end{array}$ & Bought flowers for entrance & 0.69 & 0.65 \\
$\begin{array}{l}\text { 6) Purchases for } \\
\text { other outside } \\
\text { location }\end{array}$ & Bought flowers for other occasions & 0.80 & 0.66 \\
\hline
\end{tabular}

${ }^{x}$ Factor loadings are correlations between the variable vcctor and the factor vector.

yFactor loadings of correlations above 0.40 are reported.

The amount of variance in the variable contributing to the factor.

\section{Store factors}

Store factor 1 condensed five issues that pertained to the quality of supermarket floral products (Table 3 ). The issues of supermarket floral product quality being 1) the same as a traditional retail florist's, and 2) as fresh were both strongly related to this factor. The issues of supermarket flowers being 3) a better bargain than a traditional retail florist's and 4) a more convenient place to buy flowers were somewhat less positively related. The issue of 5) purchasing flowers for everyday occasions was also related to this factor.

Store factor 2 was related to the supermarket's image only. The factor described the consumer's perception of the supermarket product mix as being similar when compared with a traditional florist's product mix.

\section{Gift (use) factors}

Gift factor 1 expressed buying flowers for a holiday family meal (Table 4). This factor condensed four survey issues that included past purchases for 1) Easter, 2) Thanksgiving, 3) Christmas, and 4) for use in the dining room. These issues comprised a factor that accounted for the use of floral products during special family occasions that have a special, more elaborate main meal associated with them.

Gift factor 2 related to purchasing a floral product for a mother. The four issues that comprised this factor were the consumer's purchase of flowers for 1) a parent regardless of occasion or event, 2) Mother's Day, 3) a birthday, and 4) a grandparent. This factor indicated that the purchase of flowers for a mother was expressed uniquely from purchases for the father.

Gift factor 3 defined the purchase of flowers after the death of an individual. Three issues related to this factor are purchases of flowers for 1) Memorial Day, 2) the cemetery, and 3) a funeral. Although these flow- ers are not given in the traditional sense of a floral gift, these purchases are nonetheless made for an individual(s) other than the floral-product purchaser.

Gift factor 4 identified purchases of floral products for men as a unique factor. Three issues were condensed in this factor: 1) consumer agreement that men like to receive flowers as much as women, 2) past consumer purchase of flowers for male friends, and 3 ) consumers liking to have flowers near them at work. The extraction of this factor indicated the consumer's perception of buying flower products for men was different from buying flowers for a parent, spouse, or others.

Gift factor 5 defined a factor of purchasing floral products for coworkers or colleagues. Two survey issues, 1) buying flowers for a coworker and 2) buying flowers for the office, were positively related to this factor.

Gift factor 6 expressed the consumer's purchase of flowers for women. The factor was-comprised of three issues: 1) past purchase of a floral product for a spouse, 2) for an anniversary, and 3) the lack of purchase of flowers for a female friend. The emergence of this factor indicated that floral purchases for women are related to their marital status.

Gift factor 7 quantified the purchase of flowers for a wedding. The three issues that loaded on this factor were past purchase of a floral product for 1) a daughter, 2) a wedding, and 3 ) a place of worship. Just as funeral flowers emerged as a unique floral gift factor, wedding flowers appeared to be perceived as a unique floral gift to be used, in most instances, by someone other than the floral purchaser.

Gift factor 8 identified the purchase of floral products for a special event. The two ispurchases of a floral product for a special event and 2) the purchase of flowers for ansues related to this factor were 1) past other relative. This factor capsulized floral purchasing for an individual at a time other than a traditional, formal holiday or regularly occurring occasion.

Gift factor 9 identified the single issue of purchasing flowers for Father's Day. The emergence of this factor indicated that consumers perceived buying flowers for a father as distinct from buying flowers for a mother or men in general.

\section{Location use factors}

Location factor 1 quantified the consumer's use of floral products outside the home (Table 5). Three survey issues comprised this factor: buying floral products for 1) outside places, including the yard and patio; 2) the yard; and 3) for the porch or patio. These issues together expressed a continuum of floral-product use outside the home rather than in specific locations inside the home.

Location factor 2 defined the placement of flowers inside the home and was measured by two survey issues: past purchase of flowers for 1) the bathroom and 2) the kitchen. This factor indicated two rooms where flowers were likely to have been placed when used in the home.

Location factor 3 identified a continuum of using flowers on clothing. Only one issue, "I like to wear flowers," was related to the factor. This factor indicated that wearing floral products was considered a unique way to use flowers by the consumer.

Location factor 4 condensed two issues relating to placement of floral products in the home, buying flowers for 1) the study and 2) the entrance.

Location factor 5 was a single-issue factor: purchase of flowers in the previous year for an occasion other than those mentioned. The factor accounted for events for which flowers were purchased and not probed in the questionnaire.

Location factor 6 was a single-issue factor that captured information not specifically probed in the survey; the consumer's purchase of flowers for use in a place outside the home not mentioned in the survey was strongly correlated with this factor.

The 34 factors related to either consumer, the product, the location of purchase, or the use of the floral product in a particular location or by an individual. Four of the five groups of factors described are similar to the four components found in a gift-giving paradigm described by Belk (1976). The four components of Belk's model were: 1) the giver, 2) the product (gift), 3) the individual's perception of him/herself, and 4) the gift recipient. The floral purchasing factors identified here were condensed into a similar framework: 1) consumer factors, 2) product factors, and 3 ) use of the product either by one or more persons (or the purchaser). The factors that relate to the store could be considered, in a broad sense, to pertain to the product.

Belk's paradigm gave structure to giftgiving situations that comprise a significant portion of floral purchases. From a broad 
perspective, even flowers that are bought for use by the purchaser could be considered a gift to himself/herself. Thus, the 91 survey measures used in this research were condensed into 34 factors that pertain to the floral purchaser, the intended user (personal or gift), and the floral product itself.

Each factor is expressed on a continuum, which means that consumers can be scored on each factor. The factors themselves are useful in that they substantially reduce the dimensions of consumer-floral purchasing. They are most useful when consumers are scored on each factor. The consumer factor scores can be used to determine homogeneous groups or market segments. Future research should focus on using these factors in a consumer-segmentation analysis.

One approach divided supermarket floral consumers into five segments based on these 34 factors and demographic variables (Behe et al., 1992). Fourteen factors contributed most to the differences between segments, including factors of product assortment, number of purchases, degree of personal use, and package importance. Clusters can be used by supermarket and florist management as potential target markets.

Other segmentations could focus on the role of these 34 factors in identifying individuals likely to purchase certain kinds of floral products and services or predicting the likelihood of the next floral purchase.

\section{Literature Cited}

Baker, M.E. 1961. An analysis of the sale of cut flowers and potted plants through supermarkets. PhD Diss., The Ohio State Univ., Columbus.

Belk, R.W. 1976. It's the thought that counts: A signed diagraph analysis of gift-giving. J. Consumer Res. 3:155-161.

Behe, B.K., T.A. Prince, and H.K. Tayama. 1992. Market segmentation of supermarket floral customers. HortScience 27:459-462.

Berekoven, L., K. Specht, V. Walthelm, and F. Wimmer. 1975. The representativeness of mail survey research. Jahrbuch der Absatz und Verbrauchsforschung 21:184-206.

Broschat, T.K. 1979. Principal component analysis in horticultural research. HortScience 14:114117.

Dillman, D.A. 1978. Mail and telephone surveys: The total design method. Wiley-Interscience Publ., New York.

Goodrich, D.C., Jr. 1980. Part II: The supermarket view. Floral Marketing Chain Store Publ. Corp., New York.

Green, P. 1978. Analyzing multivariate data. Dryden, Hinsdale, Il.

Guttman, L. 1954. Some necessary conditions for common factor analysis. Psychometrika 19:149161.

Hutchinson, N.R. and J.L. Robertson. 1979. Consumer demand analysis for roses. J. Amer. Soc. Hort. Sci. 104:303-308.

Kaiser, H. 1958. The varimax criterion for analytic rotation in factor analysis. Psychometrika. 19:149-161.

Kress, G. 1987. Super survey. Soc. Amer. Florists 14(8):24-29.

Market Facts. 1985. Soc. Amer. Florist's Floral Mktg. Rpt. Submitted by Market Facts. Washington, D.C.

Market Facts. 1989. Soc. Amer. Florists Floral Mktg. Rpt. Washington, D.C.

HortScience, Vol. 27(5), May 1992
Miller, M.N. 1977. Consumer preferences for and attitudes toward cut flower items in supermarkets. MS Thesis, Purdue Univ., West Lafayette, Ind.

Peterson, R.A. 1982. Marketing research. Business Publ., Plano, Texas.

Robertson, J.L. and D.E. Hahn. 1978. Analysis of demand for potted chrysanthemums in supermarkets. J. Amer. Soc. Hort. Sci. 103:203206.

Sherman, R.W., D.C. Kiplinger, and H.C. Williams. 1956. Consumer preferences for cut roses, carnations, and chrysanthemums. Ohio Agr. Expt. Sta. Res. Circ. 31.

$\overline{ }$ 